\title{
RANCANG BANGUN LAS (OAW) OXY ACETYLIN WELDING BERBAHAN BAKAR GAS ACETYLIN UNTUK MENINGKATKAN MINAT BELAJAR MAHASISWA TEKNIK MESIN UNIVERSITAS HASYIM ASY`ARI
}

\author{
Ali Hasbi R \\ Teknik Mesin, Fakultas Teknik, Universitas Hasyim Asy’ari, Email : alihasbi89@gmail.com
}

Retno Eka P.S

Teknik Mesin, Fakultas Teknik, Universitas Hasyim Asy'ari, Email :

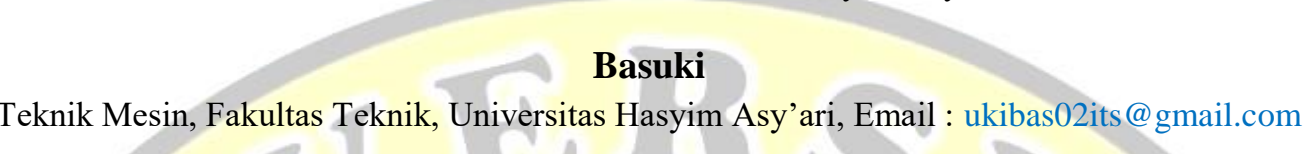

Fajar Satriya H

Teknik Mesin, Fakultas Teknik, Universitas Hasyim Asy’ari, Email :

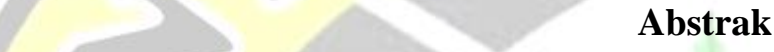

Penelitian ini merupakan penelitian eksperimen, yang mana peneliti merancang desain, kemudian dibentuk menjadi prototype las oxy acetylin yang akan dipergunakan dalam kegiatan praktikum pengelasan. Subyek penelitian merupakan mahasiswa teknik mesin angkatan 2015 sebanyak 19 orang mahasiswa.

Hasil penelitian menunjukkan bahwah Rancang Bangun Las (OAW) Oxy Acetylin Welding Berbahan Bakar Gas Acetylin berfungsi dengan baik serta dapat Meningkatkan Minat Belajar Mahasiswa Teknik Mesin pada Mata Kuliah Pengelasan di Universitas Hasyim Asy'ari Tebuireng Jombang, hal ini dapat dilihat dari beberapa indikator minat yang menjadi penilaian. Indikator rasa suka menunjukkan nilai 77,63\%, Menyatakan minat pada indikator rasa suka termasuk kategori tinggi. Untuk indikator ketertarikan diperoleh nilai 75,00\%. ini menyatakan minat pada indikator ketertarikan termasuk kategori tinggi. Sedangkan hasil analisis untuk indikator memusatkan perhatian adalah $81,58 \%$. ini menyatakan minat pada indikator memusatkan perhatian termasuk kategori sangat tinggi. Untuk indikator keaktifan siswa diperoleh nilai 66,78\%. ini menyatakan minat pada indikator keaktifan siswa termasuk kategori tinggi. Kemudian indikator rasa percaya diri nilai 80,53\%. ini menyatakan minat pada indikator rasa percaya diri termasuk kategori tinggi.

Kata Kunci: Mahasiswa, proses pengelasan, las acetylin, minat belajar.

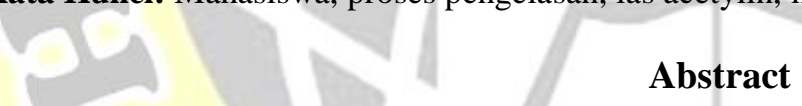

This research is an experimental study, in which the researcher designed the design, then formed into a prototype weld oxy Acetylin that will be used in the practice of welding practicum. The research subject is a mechanical engineering student of 2015 as many as 19 students.

The results of the research showed that the building of the design of welding (OAW) Oxy Acetylin Welding fueled Acetylin Gas works well and can increase the learning interest of mechanical engineering students on welding courses at the University of Hasyim Asy'ari Tebuireng Jombang, this can be seen from several indicators of interest that become judgment. The liking indicator shows a value of $77.63 \%$, expressed interest in the liking indicators including the high category. For interest indicators obtained $75.00 \%$ value. expressed interest in interest indicators including high category. While the analysis results for the focusing indicator is $81.58 \%$. This expressed interest in the focused indicator including the very high category. For the active indicators students obtained a value of $66.78 \%$. This expressed interest in the student's active indicators including high category. Then the confidence indicator values of $80.53 \%$. This expresses interest in the confidence indicator including the high category.

Keywords: students, welding processes, welding acetylin, learning interests. 


\section{PENDAHULUAN}

Tujuan utama sebuah lembaga atau instansi pendidikan terutamanya Universitas Hasyim Asy'ari adalah memberikan bekal pemahaman dan ketrampilan untuk mempersiapkan lulusannya memenuhi kriteria DU/DI (Dunia Usaha dan Dunia Industri). Berbagai upaya secara khusus telah dilaksanakan seperti perbaikan kurikulum yang terus menerus berkembang. Karena pada hakekatnya sebuah Universitas atau instansi pendidikan berorientasi pada dunia kerja, meliputi kemampuan pemahaman akan teori dan ketrampilan praktek, maka kualitas lulusannya adalah tolak ukur untuk memenuhi tuntutan kualifikasi dunia kerja .

Mahasiswa Fakultas Teknik khususnya jurusan Teknik Mesin harus dibekali dengan ketrampilanketerampilan keteknikan salah satunya mengelas untuk mendukung kemampuan agar siap bersaing dan memenuhi kriteria dunia kerja utamanya jenis pekerjaan yang terkait dengan pekerjaan konstruksi logam. Hal ini sangat penting karena pada kurikulum teknik mesin Universitas Hasyim Asy'ari mata kuliah teknik pengelasan termasuk mata kuliah wajib.

Belajar pengelasan pada hakekatnya adalah belajar membuat produk konstruksi logam, jika dilihat dari pengertianya Pengelasan adalah salah satu teknik penyambungan logam dengan cara mencairkan sebagian logam induk dan logam pengisi dengan atau tanpa tekanan dan dengan atau tanpa logam tambahan dan menghasilkan sambungan yang kontinu (Wiryosumarto, 1996). Dari konsep yang telah dipaparkan maka keterampilan pengelasan merupakan suatu hal penting baik waktu sekarang maupun yang akan datang. Lulusan yang mahir pengelasan lebih mudah membuat produk konstruksi logam yang memerlukan banyak sambungan logam.

Berdasarkan temuan pada proses perkuliahan di temukan mahasiswa yang kurang mahir dalam pengelasan. Hal ini disebabkan karena terbatasnya peralatan yang ada pada laboratorium pengelasan sehingga tidak proporsional antara jumlah mahasiswa dengan jumlah peralatan disamping peralatan las yang selama ini hanya las busur listrik. Oleh sebab itu maka diperlukaannya peralatan pengelasan untuk meningkatkan kompetensi mahasiswa di bidang pengelasan seperti las Oxy Acetyline, Jenis las ini lazim disebut OAW atau Oxy Acetyline Welding. Sedang jika gas bakarnya bukan acetylin tetapi propan atau buatan disebut OFW atau Oxy Fuel Welding (Sri widharto, 1987). Dalam proses las oxy-acetylin, gas yang digunakan adalah campuran dari gas oksigen $\left(\mathrm{O}_{2}\right)$ dengan gas acetylin $\left(\mathrm{C}_{2} \mathrm{H}_{2}\right)$ sebagai gas bahan bakar

Perancangan alat Oxy Acetyline Welding juga diharapkan dapat meningkatkan minat mahasiswa, karena selain keterbatasan alat pengelasan ditemukan sebab lain yaitu minat belajar yang kurang sehingga hasil belajar tidak maksimal.

Minat merupakan salah satu faktor yang mempengaruhi prestasi belajar. Menurut Djaali (2011:121) minat adalah rasa lebih suka dan rasa ketertarikan pada suatu hal atau aktivitas, tanpa ada yang menyuruh. Minat merupakan penerimaan akan suatu hubungan antara diri sendiri dengan sesuatu di luar diri. Semakin kuat atau dekat hubungan tersebut, semakin besar minatnya. Minat menurut Whiterington (1985:136) dibagi menjadi dua jenis, yaitu: (a) Minat biologis atau minat primitif, yaitu minat yang timbul dari kebutuhankebutuhan yang berkisar pada hal makan dan kebebasan beraktifitas, (b) Minat sosial atau minat kultural, yaitu minat yang berasal dari belajar yang lebih tinggi sifatnya, minat ini meliputi: kekayaan, bahasa simbol, harga diri, atau prestise sosial, dan sebagainya. Menurut Hadinoto (1998:189) ada dua faktor yang mempengaruhi minat seseorang, yaitu (a) Faktor dari dalam (intrinsik) yaitu berarti bahwa sesuatu perbuatan memang diinginkan karena seseorang senang melakukannya. Di sini minat datang dari diri orang itu sendiri. Orang tersebut senang melakukan perbuatan itu demi perbuatan itu sendiri, (b) Faktor dari luar (ekstrinsik) yaitu berarti bahwa sesuatu perbuatan dilakukan atas dasar dorongan atau pelaksanaan dari luar. Orang melakukan kegiatan ini karena ia didorong atau dipaksa dari luar.

Berdasarkan paparan masalah diatas peneliti mencoba meningkatkan minat mahasiswa dengan membuat media pembelajaran berupa mesin pengelasan sederhana dan tidak membutuhkan biaya besar dengan kualitas pengelasan yang baik. Jenis mesin pengelasan tersebut adalah mesin las (OAW) Oxy Acetylin Welding hal ini tidak lain untuk meningkatkan kompetensi mahasiswa di bidang pengelasan khususnya jurusan teknik mesin, fakultas teknik, Universitas Hasyim Asy`ari.

\section{METODE PENELITIAN}

Penelitian ini menggunakan jenis penelitian kuantatif deskriptif, menurut Mukhadis (2016:70) penelitian kuantitatif adalah penelitian yang tuntutan kedalaman dalam melakukan analisis data sebagai wahana memformulasikan interpretasi hanya sampai pada deskripsi, pemerian, pemetaan, dari variabel yang dijadikan hanya objek satu demi satu. Yang mana peneliti merancang bangun pengelasan oxy acetylin serta mendeskripsikan minat belajar mahasiswa teknikmesin pada mesin las OAW.

Subyek dalam penelitian ini adalah mahasiswa program studi teknik mesin tahun ajaran 2017/2018, obyek dalam penelitian ini adalahlas oxy acetylin yang menggunakan bahan bakar gas oksigen dan gas Acetylin. Serta sasaran penelitian ini adalah mahasiswa S1 program studi Teknik Mesin angkatan 2016.

Tempat penelitian ini di laboratorium teknik mesin Universitas Hasym Asy'ary. Waktu pelaksanaan penelitian adalah Agustus-Desember.

Adapun kerangka penelitian bisa dilihat pada Gambar 1 dibawah ini. 


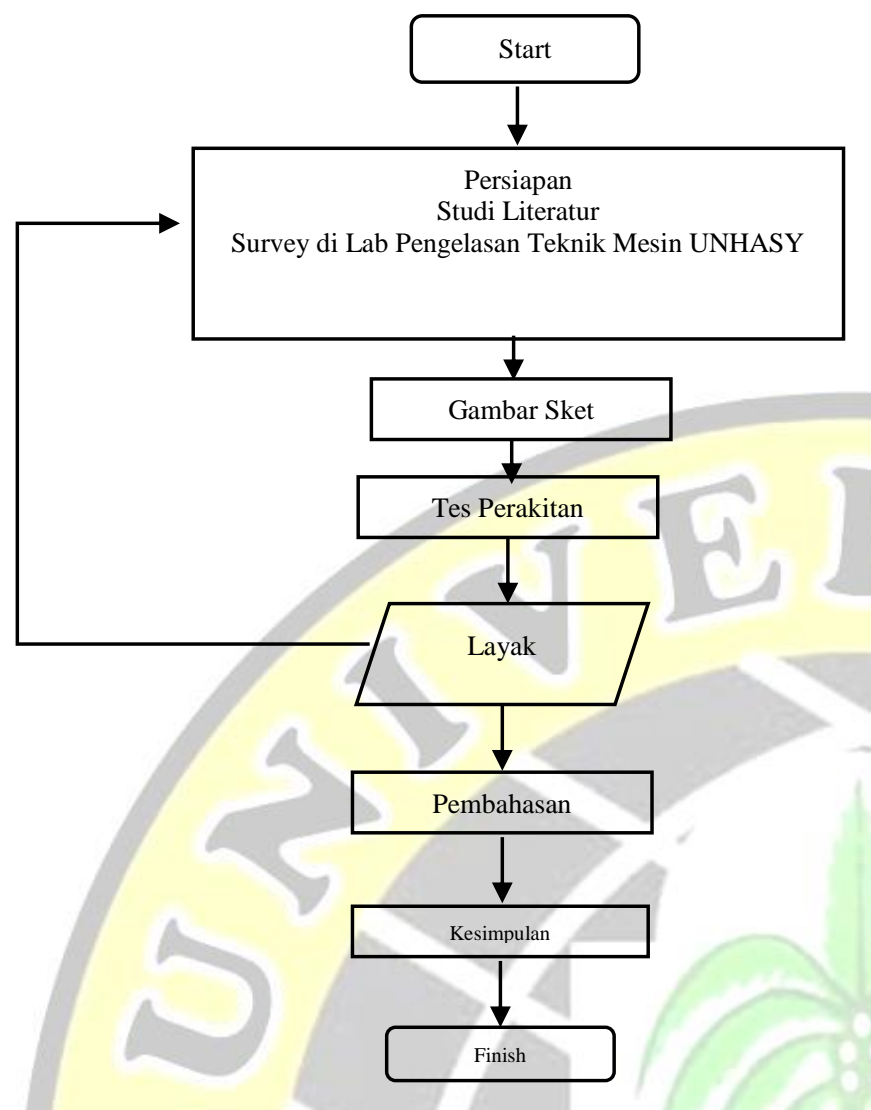

Gambar 1 Flow chart penelitian

\section{HASIL DAN PEMBAHASAN \\ a. Rancang bangun mesin las (OAW) Oxy Asitylin Welding}

Rancang bangun mesin las asetylin (OAW) adalah merupakan pengembangan proses pengelasan yang menggunakan dua bahan bakar utama yaitu oksigen dan gas asetylin. Metode penelitian yang digunakan adalah metode rancang bangun sekaligus penerapan pada sebuah mesin sekaligus dilakukan pengujian. Rancang bangun mesin las asetylin dikerjakan di laboratorium pengelasan. Tujuan dirancangnya mesin ini adalah sebagai sarana penunjang praktikum mata kuliah pengelasan sehingga dapat meningkatkan minat belajar mahasiswa.
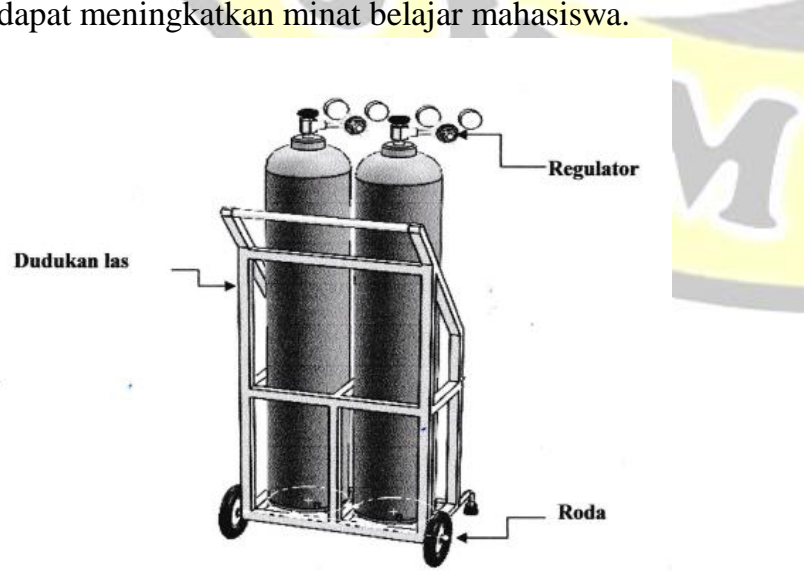

Gambar di atas menunjukkan rancang bangun mesin las Oxy Acetylin Welding (OAW). Pada mesin las OAW terdiri beberapa komponen antara lain : tabung asetylin, tabung oksigen, regulator, selang oksigen, selang asetylin, brander dan dudukan mesin. Las Oxy acetylin merupakan pengelasan secara manual, dimana benda yang akan disambung mengalami pemanasan sampai mencair oleh nyala (flame) gas asetylin yaitu pembakaran $\mathrm{C}_{2} \mathrm{H}_{2}$ dengan $\mathrm{O}_{2}$, dengan atau tanpa logam pengisi, serta proses penyambungan tanpa penekanan. Disamping untuk keperluan pengelasan ( penyambungan ) las asetylin juga dapat dipergunakan sebagai : preheating, brazing, cutting dan hard facing. Dalam aplikasinya las OAW sangat cocok untuk pengerjaan lembaran lembaran logam dan pipa - pipa yang tipis yang mempunyai ketebalan kurang dari $3 \mathrm{~mm}$.

Disamping gas acetylin digunakan juga gas hydrogen, gas alam, propane, untuk logam dengan titik cair rendah. Pada proses pembakaran gas tersebut diperlukan adanya oxygen. Oxygen ini didapat dari udara bebas yang mengandung oksigen (21\%), kemudian mengandung nitrogen ( $78 \%)$, serta argon $(0,9 \%)$, neon, hydrogen,carbon dioksida, dan unsur lain yang membentuk gas.

Dengan proses pengelasan yang benar, teknik dan meterial sesuai standar, akan diperoleh pengelasan yang berkualitas. Tetapi pengelasan oxy-asitelin juga dimungkinkan terjadi cacat las. Cacat yang sering terjadi pada proses pengelasan Oksi-Asetilin antara lain :

\section{Undercutting}

Cacat las ini disebabkan oleh penggunaan parameter tekanan gas yang kurang tepat, terutama kecepatan pengelasan dan tekanan gas yang tidak sesuai. proses pengelasan yang terlalu cepat dapat mengakibatkan undercutting terjadi. Dengan mengurangi kecepatan pengelasan akan dapat meminimalisir besarnya undercutting bahkan dapat menghilangkannya.

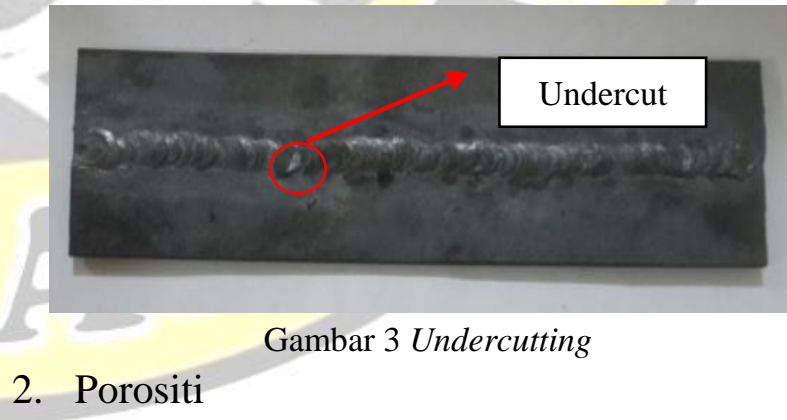

Porositi adalah lubang yang disebabkan oleh gelembung gas yang telah membeku. Penyebab utama dari porositi adalah kontaminasi atmosfer, oksidasi yang tinggi pada permukaan benda kerja.

Gambar 2 Mesin las OAW 


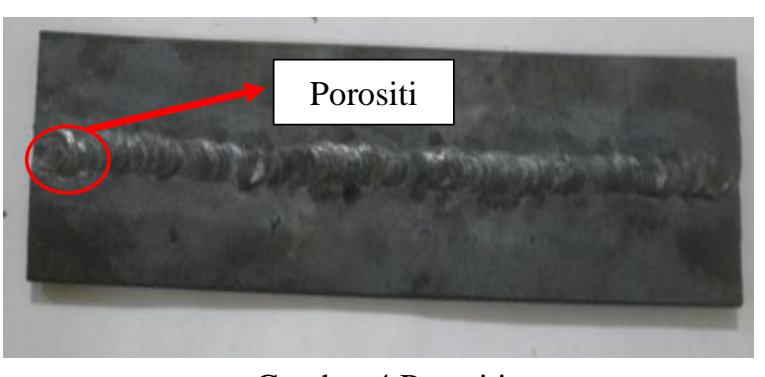

Gambar 4 Porositi

\section{Keretakan crater}

Keretakan ini terjadi pada ujung hasil pengelasan hal tersebut disebabkan oleh kesalahan dalam teknik akhir pada saat pengelasan. Cara megatasi keretakan cseater dengan cara membalikkan arah pengelasan pada akhir pengelasan.

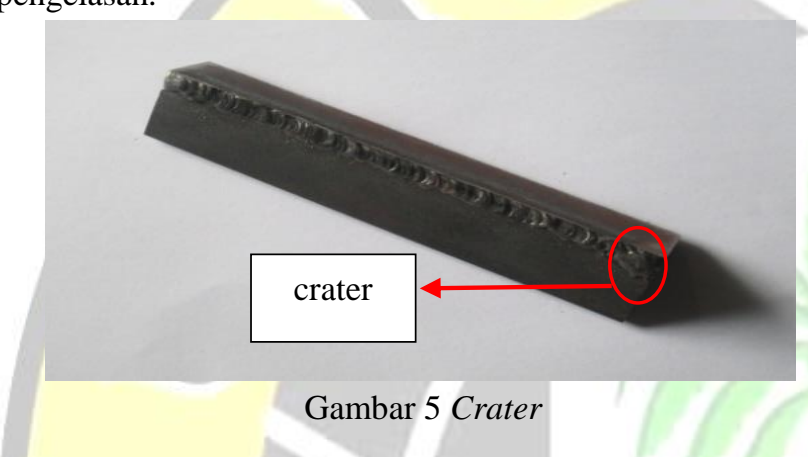

\section{b. Minat Belajar Mahasiswa setelah Pengadaan Mesin Las(OAW) Oxy Acetylin Welding}

Minat belajar mahasiswa teknik mesin setelah terbentuknya mesin las (OAW) Oxy acetelyn Welding disajikan pada Tabel 1 berdasarkan persentase dan kategori.

Tabel 1 Minat mahasiswa

\begin{tabular}{|c|c|c|c|}
\hline \multirow{2}{*}{ No } & \multirow{2}{*}{ Indikator } & \multicolumn{2}{|c|}{ Minat mahasiswa } \\
\cline { 3 - 4 } & Rersentase & Kategori \\
\hline 1 & Rasa suka & $77,63 \%$ & Tinggi \\
\hline 2 & Ketertarikan & $75,00 \%$ & Tinggi \\
\hline 3 & $\begin{array}{c}\text { Memusatka } \\
\text { n perhatian }\end{array}$ & $81,58 \%$ & Sangat tinggi \\
\hline 4 & $\begin{array}{c}\text { Keaktifan } \\
\text { mahasiswa }\end{array}$ & $66,78 \%$ & Tinggi \\
\hline 5 & $\begin{array}{c}\text { Rasa } \\
\text { percaya diri }\end{array}$ & $80,53 \%$ & Tinggi \\
\hline
\end{tabular}

Berdasarkan tabel 1 menunjukkan bahwa indikator rasa suka rata-rata 3,14 dengan 84,21 responden. Hal ini menyatakan minat pada indikator rasa suka termasuk kategori tinggi. Untuk indikator ketertarikan rata-rata 2,74 dengan 78,94\%. ini menyatakan minat pada indikator ketertarikan termasuk kategori tinggi. Untuk indikator memusatkan perhatian rata-rata 3,05 dengan 94,74\%. ini menyatakan minat pada indikator memusatkan perhatian termasuk kategori tinggi. Untuk indikator keaktifan siswa rata-rata 3,28 dengan 94,74\%. ini menyatakan minat pada indikator keaktifan siswa termasuk kategori sangat tinggi. Untuk indikator rasa percaya diri rata-rata 3,26 dengan $89,47 \%$. ini menyatakan minat pada indikator rasa percaya diri termasuk kategori sangat tinggi.

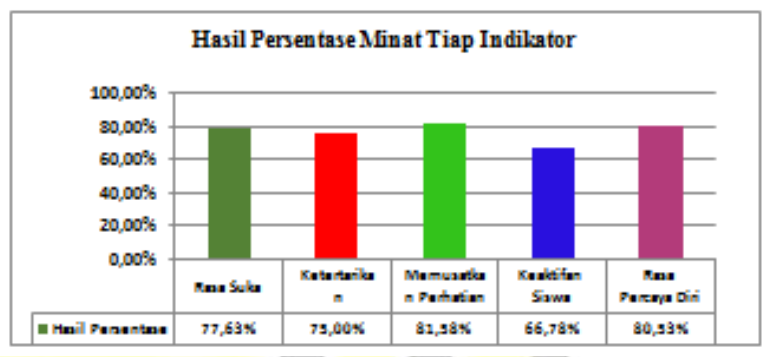

Gambar 6 Diagram Minat Mahasiswa

\section{PENUTUP}

\section{Simpulan}

Rancang Bangun Las (OAW) Oxy Acetylin Welding Berbahan Bakar Gas Acetylin berfungsi dengan baik. Dengan terciptanya Las (OAW) Oxy Acetylin dapat dapat meningkatkan Minat Belajar Mahasiswa Teknik Mesin pada Mata Kuliah Pengelasan di Universitas Hasyim Asy'ari Tebuireng Jombang, hal ini dapat dilihat dari beberapa indikator minat yang menjadi penilaian. Indikator rasa suka menunjukkan nilai $77,63 \%$, Hal ini menyatakan minat pada indikator rasa suka termasuk kategori tinggi. Untuk indikator ketertarikan diperoleh nilai $75,00 \%$. ini menyatakan minat pada indikator ketertarikan termasuk kategori tinggi. Sedangkan hasil analisis untuk indikator memusatkan perhatian adalah $81,58 \%$. ini menyatakan minat pada indikator memusatkan perhatian termasuk kategori sangat tinggi. Untuk indikator keaktifan siswa diperoleh nilai $66,78 \%$. ini menyatakan minat pada indikator keaktifan siswa termasuk kategori tinggi. Kemudian indikator rasa percaya diri nilai $80,53 \%$. ini menyatakan minat pada indikator rasa percaya diri termasuk kategori tinggi.

\section{DAFTAR PUSTAKA}

Wiryosumarto, Harsono. Publisher. 1996. Teknologi Pengelasan Logam. Jakarta : Pradnya Paramita.

Witherington. 1985. Psikologi Pendidikan. Jakarta: Aksara Baru

Djaali, 2011. Psikologi Pedidikan. Jakarta: Bumi Aksara Mukhadis, A. 2016. Metodologi Penelitian Kuantitatif: Contoh Aplikasinya dalam Bidang Pendidikan. Malang: Aditya Media Publishing

Sri Widharto, 1987. Petunjuk Kerja Las: Jakarta : Pradnya Paramita 